\title{
Pandemics and Post-Pandemic Times
}

\author{
Hakan Sönmez \\ Vrije Universiteit Brussel (VUB)
}

\begin{abstract}
This essay investigates some of the major pandemics in human history and scrutinizes their sociological, economic, and political pay-offs. To what extent can pandemics transform our society? How do the pandemics in history relate to the current? The Plague of Athens caused disappointment towards Greek gods since the Athenians felt they were not getting enough support from Apollo. The Plague of Justinian brought revolts across the empire and led to the end of Classical Antiquity. The Black Death changed the future vision of Europeans significantly because death was omnipresent. Although the death toll of cholera pandemic was limited, it triggered stigmatization, violence, and racism towards Asian people, especially to Indians. The Spanish conquistador Hernán Cortés would never have been able to colonize the Aztec civilization without the smallpox outbreak. After an episode of absurdism and Dadaism, the Spanish flu brought the Roaring Twenties with widespread use of radio, dance-halls, jazz, Harlem Renaissance, gay and lesbian scenes, and women's suffrage. Coronavirus pandemic shows that society is digitizing at light speed among the art world. This essay also shows that our economy is a positive-sum economy in contrast to the zero-sum economy in times of the Black Death and before. There is also a delicate balance that must be maintained between keeping the pandemic under control and respecting the democratic principles. The essay concludes that each pandemic has an idiosyncratic nature and a pandemic can have different effects in different societies or regions in the world.
\end{abstract}

Keywords Pandemics - Bubonic - Cholera - Coronavirus - Covid-19 - Smallpox - Spanish Flu.

\section{Submission}

$$
\text { 14/05/202I Approval }
$$

Publication

$\mathrm{IO} / \mathrm{IO} / 2 \mathrm{O2I}$ 


\section{Pandemias e tempos pós-pandêmicos}

\section{Resumo}

Este ensaio investiga algumas das principais pandemias da história humana e examina seus resultados sociológicos, econômicos e políticos. Em que medida as pandemias podem transformar nossa sociedade? Como as pandemias na história se relacionam com a atual? A Peste de Atenas impactou a fé de seus cidadãos nos deuses, pois os atenienses sentiram que não estavam recebendo apoio suficiente de Apolo. A Peste de Justiniano trouxe revoltas por todo o império e levou ao fim a Antiguidade Clássica. A Peste Negra mudou significativamente a visão futura dos europeus porque a morte foi onipresente. Embora o número de mortos na pandemia de cólera tenha sido limitado, ela desencadeou estigmatização, violência e racismo contra os asiáticos, especialmente os indianos. O conquistador espanhol Hernán Cortés nunca teria sido capaz de colonizar a civilização asteca sem o surto de varíola. Depois de um episódio surreal e dadaísta, a gripe espanhola trouxe os loucos anos vinte, de uso generalizado de rádio, dos salóes de dança, do jazz, a Renascença do Harlem, o cenário gay e lésbico e o sufrágio feminino. A pandemia do coronavírus mostra que a sociedade está se digitalizando na velocidade da luz entre o mundo da arte. Este ensaio também mostra que nossa economia é de soma positiva, em contraste com a de soma zero dos tempos da Peste Negra e de antes. Há também um equilíbrio delicado que deve ser mantido entre manter a pandemia sob controle e respeitar os princípios democráticos. O ensaio conclui que cada pandemia tem uma natureza idiossincrática e que ela pode ter efeitos distintos em diferentes sociedades ou regióes do mundo.

Palavras-chave Pandemias - Bubônica - Cólera - Coronavírus - Covid-ı9 - Gripe espanhola Varíola.

\section{Pandémies et temps post-pandémiques}

\section{Résumé}

Cette essai examine certaines des principales pandémies de l'histoire humaine et leurs effets sociologiques, économiques et politiques. Dans quelle mesure les pandémies peuvent-elles transformer notre société? Comment les pandémies de l'histoire sont-elles liées aux pandémies courantes? La peste d'Athènes a causé une déception envers les dieux grecs car les Athéniens ont estimé qu'ils ne recevaient pas suffisamment de soutien d'Apollon. La peste de Justinien a provoqué des révoltes dans tout l'empire et a conduit à la fin de l'Antiquité classique. La 'peste noire' a considérablement changé la vision future des Européens car la mort était omniprésente. Bien que le nombre de morts de choléra ait été limité, cette pandémie a déclenché la stigmatisation, la violence et le racisme envers les Asiatiques, en particulier les Indiens. Le conquéreur espagnol Hernán Cortés n'aurait jamais pu coloniser la civilisation aztèque sans l'épidémie de variole. Après un épisode d’absurdisme et de dadaïsme, la grippe espagnole a apporté les années folles avec une généralisation de la radio, des salles de danse, du jazz, de la Harlem Renaissance, des scènes gays et lesbiennes, et du suffrage féminin. La pandémie de coronavirus montre que la société se numérise à la vitesse de la lumière dans le monde des arts. Cet essai montre également que notre économie est une économie à somme positive contrairement à l'économie à somme nulle à l'époque de la peste noire et avant. Il existe également un équilibre délicat qui doit être maintenu entre la maitrise de la pandémie et le respect des principes démocratiques. L'essai conclut que chaque pandémie a une nature idiosyncratique et qu'une pandémie peut avoir des effets divers dans différentes sociétés ou régions du monde.

Mots-clés Pandémies - Bubonique - Choléra - Coronavirus - Covid-I9 - Grippe espagnole Variole.

$2 \cdot$ ano XII, n. I7, 202I • ISSN 2179-5487 


\section{Introduction}

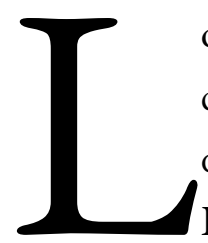

ouis Pasteur and Robert Koch were inter alia big rivals but their contribution to the establishment of bacteriology as a new scientific discipline revolutionized the whole conception of infectious diseases. ${ }^{1}$ Pasteur identified the microorganismal causes of communicable diseases and demonstrated how to make vaccines from attenuated microbes. Koch founded the bacteria that cause anthrax, septicaemia, tuberculosis and cholera, and his methods opened a new way for others to discover more pathogens.

Kitasato Shibasaburō discovered the Pasteurella pestis (later named Yersinia pestis) as the bacterial cause of bubonic plague during the outbreak in Hong Kong on June I4, I894, but his description lacked precision. Alexandre Yersin, then head of the Pasteur Institute, was also able to isolate the organism from human tissues during the same plague on June 23, I894. Spontaneous plague in rodents has been suspected since the pandemic of 1855 in Yunnan ${ }^{2}$ but its contamination through fleas was first suggested by Masanori Ogata in 1897 . The theory was further developed by William Glen Liston in I905, and the mechanism of transmission by Arthur William Bacot in 1914. ${ }^{3}$ This was the beginning of the end of Yersinia pestis. The diagnostic results allowed Yersin to experiment with a first anti-plague serum in 1895 , but it had not a great success in healing the patients. The current treatment of plague consists of antibiotics, dispense of oxygen, intravenous therapy, and respiratory support. ${ }^{4}$

The Italian anatomist, Filippo Pacini, discovered the Vibrio cholerae bacillus (commonly known as cholera) in I854. However, all credit is given to Robert Koch because of his extensive field research and publications about the disease in the I88os. In I885, Jaime Ferrán, who studied under Louis Pasteur, became the first developer of the cholera vaccine. He did so after cultivating Vibrio cholerae bacillus and working with live germs.

Another triumph in the medical field was the development of smallpox vaccine by Edward Jenner, a discovery of prime importance, especially for people in the Western

\footnotetext{
I CASTIGLIONI, A. A History of Medicine. 2nd ed. New York: Alfred A. Knopf, 1947.

2 Ibidem.

3 Ibidem.

4 DENNIS, D. T.; GAGE, K. L. Plague Manual: Epidemiology, Distribution, Surveillance and Control. Geneva: World Health Organization, 1999.
} 


\section{REVISTA ANGELUS NOVUS}

Hemisphere considering the fact that smallpox was already known in the Eastern Hemisphere since very ancient times.

In 1928, Alexander Fleming showed up with his penicillin $G$, which was a great victory on some of the most dangerous infectious diseases. ${ }^{5}$ It is not a secret anymore that penicillin was one of the major advancements in the early twentieth century, however, this "miracle drug" had a considerable impact on population growth. Aware of the fact, Florey was concerned about his role in the development of penicillin:

I suppose we're glad now that it works, but then you've got to see the reverse side of the

[Nobel] medal, because I'm now accused of being partly responsible for the population explosion, which is one of the most devastating things that the world has got to face for the rest of the century. ${ }^{6}$

In 1927 , the estimated world population was only 2 billion. At current, the population growth has come to gargantuan numbers, chiefly through the gradual disappearance of plagues and better health services.

The essay at hand has not the aim to follow the thread of developments in medical history, but to make it easier for the reader to follow the thoughts and arguments throughout it, and to provide comprehensive portrait of some of the major pandemics in human history and to scrutinize their sociological, economic, and political pay-offs. History has endless examples of pandemics, but they need to be compiled and filtered ideally through the methods of social science and history. The practice of such a complex task cannot be attained without extensive research with primary sources, in the first place, and, in the second place, with secondary sources or studies of the past in light of criticism of historical accounts. To uphold the zeal of historical study, the research approach is inspired by Fernand Braudel. Accordingly, it will not engage in the great exercise of scrutinizing a short term issue or a historical event, but instead, will focus on the longue durée. 7 The crux of this idea is, as widely known, to examine the long-term effects of the topic and to draw conclusions from historical patterns.

5 Yersinia pestis is not fully eradicated yet. The last example is a small outbreak that occurred in July 2020 in the Inner Mongolia region of China. Even though it can be treated with antibiotics, people still die from the consequences of this bacterium.

6 MACFARLANE, G. Howard Florey: The Making of a Great Scientist. Oxford: Oxford University Press, 1978.

7 Bringing here an age-old debate among historians. According to Thomas Carlyle, "the history of the world is but the biography of great men," whereas Lev Tolstoy thinks that "kings and generals are the slaves of history".

$4 \cdot$ ano XII, n. I7, 202I $\bullet$ ISSN 2179-5487 


\section{The Ancient Bubonic Plague}

The amount of archival material regarding the Plague of Athens is trivial. We know from Thucydides and archaeological evidence that, starting from the second year of Peloponnesian Wars (430 BCE), the plague killed around 75,000 to Ioo,ooo Athenians, nearly $25 \%$ of the city's population. ${ }^{8}$ The disease would have entered the city through its sole port of food and supplies: Piraeus. ${ }^{9}$ Possibly, Sparta and its allies were less affected by the plague in that Thucydides has recorded the following observation: "The plague had indeed begun immediately after the Peloponnesians had invaded, and it never reached the Peloponnese to any significant extent, but spread particularly in Athens and later in other densely populated areas." ${ }^{\text {10 }}$ It should not be surprising that the plague in Athens caused disappointment towards gods. Athenian citizens were godforsaken, and would also be easily convinced that Apollo (god of healing and diseases) was fighting for Sparta. "In any case, the temples turned into sites of misery, and places of worship were filled with dead bodies. ${ }^{12}$ More importantly, the power balance in the society had changed: the size of the rich class had shrunk and their fortunes were inherited by their heirs of the middle or lower class. ${ }^{13}$ Anyhow, Athens lost its political and military strength, and an Athenian victory of the Peloponnesian Wars was not anymore within reach.

The Plague of Justinian (54I-767 EC) was very likely broke out in Eastern Asia, ${ }^{14}$ then imported into Near Asia, and later, through Egyptian ports as Pelusium into the entire Mediterranean. ${ }^{15}$ It even circulated in Northern Europe and the Arabian Peninsula. The plague devastated much of the Sassanid and Roman Empires and killed roughly a fifth of Constantinople. Procopius recorded that at its peak there were daily Io,ooo deaths in Constantinople, but this number is questionable. Under these harsh conditions, the number of farmers declined and there were not enough people to till

8 LITTMAN, R. J. "The plague of Athens: epidemiology and paleopathology". Mount Sinai Journal of Medicine, v. 76, n. 5, p. 456-467, 2009.

9 Ibidem.

Io THUCYDIDES. History of the Peloponnesian War. London: Penguin, 1963.

II Thucydides witnessed that, "After the purification, the Athenians then instituted and held for the first time the quadrennial Delian festival." It is likely that an important function of the festival was to appease Apollo after the plague because there was an important sanctuary of Apollo in Delos.

I2 THUCYDIDES, op. cit.

I3 MARTINEZ, J. "Political consequences of the Plague of Athens". Graeco-Latina Brunensia, v. 22, n. I, p. I35I46, 2017.

I4 EROSHENKO, G. A. et al. "Yersinia pestis strains of ancient phylogenetic branch o.ANT are widely spread in the high-mountain plague foci of Kyrgyzstan.” PLoS ONE, v. I2, n. I0, 2017. 


\section{REVISTA ANGELUS NOVUS}

the land. The land revenue in Constantinople decreased, the price of grain rose, and the army was weakened. Procopius wrote: "All work slackened; craftsmen abandoned all their crafts and every task which any man had in hand." ${ }_{16}$ There were revolts across the empire. Justinian's empire collapsed, even though it was at the height of its conquests. This plague brought most notably the end to Classical Antiquity. The new era brought in turn new world order with the rise of the Franks in Western Europe, the revived Goths in the sphere of influence of Romans, and the emergence of Islam in the Middle East.

The bubonic plague of 1346-52, now famously referred to as the Black Death, was one of the largest pandemics in human history. The memoir of Gabriele de' Mussi is one of the main sources about this huge public health disaster. ${ }^{17}$ We know from Mussi that Mongolian Tartar army was devastated by the disease at the ports of Caffa. If the account is true, the Mongolians were throwing infected dead corpses with catapults into the city of Caffa. What seemed like mountains of dead were thrown into the city, and the Genoese tried to dump as many bodies as they could in the Black Sea. But this is hard to believe since human-to-human transmission from the buboes is rare. According to another hypothesis, which relies more on rational thinking, the bacterium infiltrated the city through black rats or other rodents. ${ }^{18}$

Although the origin of the Black Death is dubious, its spread to Europe through fleeing Italians is fairly well documented. ${ }^{19}$ Karl Sudhoff has spent years studying this literature and has collected about two hundred chief writings on it, published between I348 and I500, including Gentile da Foligno's Consilia contra pestilentiam. ${ }^{20}$ As a result 30 to $60 \%$ of Asians, Europeans, and North Africans died. The bacterium is not contaminated by person-to-person, but by parasitic fleas (hidden in grain), black rats and other rodents (frequently carried on ships or vehicles), direct contact with materials that is contaminated with bacteria through a cut or sore in a person's skin, or respiratory droplets. Therefore, the biggest challenge in taking preventive actions against infections from Yersinia pestis is to control the rodents. It is almost impossible to put small animals in quarantine. The only effective solution is to eradicate these animals and hence to eliminate the natural focus of the plague. v. 196, p. 179-182, 1966.

I8 WHEELIS, M. "Biological Warfare at the 1346 Siege of Caffa". Historical Review, v. 8, n. 9, 2002.

I9 Ibidem.

20 CASTIGLIONI, A. A History of Medicine. 2. ed, New York: Alfred A. Knopf, 1947.

$6 \cdot$ ano XII, n. 17, 202I $・$ ISSN 2179-5487 
The Black Death became an earnest pandemic in frequently visited places. Even the kings and popes got caught by the fatal consequences of it. Contemporary French physician, Guy de Chauliac, wrote in 1363 : "[T] he father no longer visited the son or the son his father. Charity was dead and hope abandoned." ${ }^{21}$ In an attempt to take practical measurements, the system of quarantine for sailors ${ }^{22}$ came up: they had to wait about forty days in their ships before they were allowed to disembark during diseaseridden times. ${ }^{23}$ In the Republic of Venice, these measurements have led to discrimination of sailors, merchandisers, and travellers from certain countries. ${ }^{24}$ The Milanese authorities went even more cruel by giving strict house arrests and surrounding the houses with corpses of infected people. 25

European pandemics were circulating almost every 30 years, resulting in much more fatal cases. In the Ottoman Empire, by contrast, there were less lethal and frequently recurring epidemics. There are fossilized rat beds in Istanbul and Southeast Anatolia which are proving these epidemics. ${ }^{26}$ The arguments of some European scholars that there was a "Muslim reaction" to the plague and that the Ottomans were fatalistic, are baseless. ${ }^{27}$ We know from Ottoman historian-chronicler Taşköprizade Ahmed Efendi that there was to a large extent flexibility in Ottoman laws to fight the plague: according to premodern law nobody was allowed to leave the city during a disease outbreak, yet, over time it was allowed to leave the city in search of "clean air" and "preservation of health." ${ }^{28}$ There were likewise measures to prevent water pollution. By virtue of the plague, the Ottomans were in a very favourable position against the East Roman Empire. Therefore it was easier to pass the Bosphorus because the pandemic had weakened the Byzantines.

2I HIRST, F. L. The Conquest of Plague. Oxford: Oxford University Press, 1953.

22 Although the history of (self-)isolation dates back to the Old Testament, the concept of isolation (for leprosy victims) is written in the unpublished statute of the unofficial Republic of Ragusa (now Dubrovnik) in I272. The isolation regulation at the Port of Venice dates back to 1374. The first known quarantine station was established by the Republic of Ragusa in 1377. In 1403, the authorities established their first lazaretto ("maritime isolation hospital") on the Island of Santa Maria di Nazareth. In Ragusa, the law speaks about trentine (30-days). The 40-days rule, or the well-known concept of quarantine, was made official by the Venetian Senate in 1448 .

23 MARKEL, H. Quarantine! East European Jewish Immigrants and the New York City Epidemics of I892. Baltimore: The Johns Hopkins University Press, 1997.

24 BAKIJA-KONSUO, A. "Lazarettos - From Isolation to Contemporary Scientific Medical Findings". MILOSEVIC, A. (Ed.). Lazaretto in Dubrovnik: Beginning of the Quarantine Regulation in Europe. Dubrovnik: Institute for Restoration of Dubrovnik, 2018. p. 65-82.

25 Ibidem.

26 VARLIK, N. Plague and Empire in the Mediterranean World: The Ottoman Experience, 1347-160o. Cambridge: Cambridge University Press, 2015.

27 PANZAC, D. La Peste dans l'Empire Ottoman, I700-1850. Leuven: Editions Peeters, 1985.

28 TASKÖPRIZADE, A. Risala al-shifa' li-adwa' al-waba'. Cairo, I875. p. 33-39. 


\section{REVISTA ANGELUS NOVUS}

In some parts of Europe, Jews are said to have been less affected by the Black Death. They were also suspected to be the cause of it. Jewish physician Balavignus made a forced confession that Jews in Southern France had worked out a plan to poison Christians. ${ }^{29}$ The poison would consist of crushed hearts of Christians, spiders, frogs, lizards, and human flesh. The story quickly spread from Switzerland to Germany and had catastrophic consequences for the Jewish community. Numerous pogroms were carried out across Europe resulting in thousands of Jewish victims. ${ }^{30}$

Not only the behaviour of people has changed badly as it is written in the first pages of Giovanni Boccaccio's Decameron, ${ }^{31}$ but also the future vision changed significantly. Death was omnipresent, and pessimism was rising. We can trace the origins of Danse Macabre - an artistic genre of allegory on the universality of death to that period. It was produced as memento mori, to remind people of the fragility of their lives and how vain the glory of earthly life was. ${ }^{32}$ The first example was a now-lost mural at Cimetière des Innocents in Paris dating from 1424.

Beyond the devastating effects, the Black Death resulted in an improvement in material living standards for the workers, especially for the farmers in Northern and Western Europe. The one-off reduction in the population was a solitary step towards better living standards. ${ }^{33}$ They were able to negotiate for better working conditions and wages. With higher incomes, the population demanded more political power, and eventually revolted against oppression, high taxes, and serfdom, which culminated in the Peasants' Revolt of $1381 .{ }^{34}$ It was an ideal circumstance for capitalism as a system to take over from feudalism in certain regions. By contrast, some other regions, where such mortality crises had struck less relentlessly, would have been stuck in a cycle of poverty. ${ }^{35}$ For example, the plague hit Egyptian agriculture so grim that the entire economic system, which was based on intensive irrigation by the rural population,

29 GOTTHEIL, R.; JACOBS, J. "Black Death". Jewish Encyclopedia. Available from: «http://www.jewishencyclopedia.com/articles/3349-black-death».

30 Ibidem.

3I SONTAG, S. Illness as Metaphor. New York: Farrar, Straus and Giroux, 1978.

32 HeRbermanN, C.; WILliamsON, G. "Dance of Death.” MCCARTY, R. (Ed.). The Catholic Encyclopaedia. New York: Robert Appleton Company, 1908. v. 4.

33 ROSER, M. "Breaking Out of the Malthusian Trap: How Pandemics Allow Us to Understand Why Our Ancestors Were Stuck in Poverty". Our World in Data. Available from: «https://ourworldindata.org/breaking-the-malthusian-trap».

34 Ibidem.

35 RYCKBOSCH, W.; DE MÛELENAERE, N.; LAMBERT, B. "De zegeningen van de zwarte dood”. EOS Wetenschap. Available from: «https://www.eoswetenschap.eu/geschiedenis/de-zegeningen-van-de-zwartedood».

$8 \cdot$ ano XII, n. I7, 202I • ISSN 2I79-5487 
could not recover for a very long time. ${ }^{36}$ Also in Spain, the Black Death did not have the supposed beneficial effect: according to recent estimates, the level of prosperity suffered such a severe blow that the level of prosperity before 1348 was not equaled anymore until the nineteenth century. ${ }^{37}$ Under these circumstances, the aftermath of the plague did not put these countries on the path to modern economic growth.

The bubonic plague outbreaks lasted for more than 300 years..$^{38}$ The fall in the average temperature by only $\mathrm{s} \%$ caused breakdown of harvest. ${ }^{39}$ The mutually reinforcing effects of this Little Ice Age and bubonic plague presumably triggered the fall of the Ming dynasty in China, the Celali Revolts in the Ottoman Empire, the Thirty Years' War in Central Europe, and the Fronde - civil wars in France between 1648-1653 - that occurred in the midst of Franco-Spanish War..$^{\circ}$

The Naples Plague of 1656 claimed a death toll of I50,000 Neapolitans, half of the city's population. This disaster was perhaps the second worst disaster after the destruction of Pompeii by the violent eruption of Mount Vesuvius in 79 BCE. During the Great Plague of 1665 , 70,00o people in London died. The Great Plague of 1738 also affected Romania, Hungary, Ukraine, Serbia, Croatia, and Austria, which likely killed over 50,000 people. Between 1700 and I850, 94 plague epidemics were recorded in Constantinople.

The pandemic of 1855 in Yunnan - that began under the rule of Qing dynasty spread to all inhabited continents, and ultimately led to the death of more than 2 million in China, and more than $\mathrm{I} 2$ million people in India. ${ }^{41}$ Measures of the British colonial government in India included the establishment of Special Plague Committees, quarantines, isolation camps, travel restrictions, exclusion of India's traditional medical practices, and some tougher measures in the coastal cities. The populace of Pune found the measures very oppressive, and to make matters worse,

RYCKBOSCH, W.; DE MÛELENAERE, N.; LAMBERT, B. “De zegeningen van de zwarte dood”. EOS Wetenschap. Available from: «https://www.eoswetenschap.eu/geschiedenis/de-zegeningen-van-de-zwartedood».

37 Ibidem.

38 Bubonic plagues in the late medieval and early modern ages: 1346-53, 1360-63, 1374, I400, $1438-39$, I456-57, I464-66, I48I-85, I500-03, I518-3I, I544-48, I563-66, I573-88, I582-83, I592-93, I596-I602, I602-II, I623-40, I629-3I, I632-25, I636-37, I641-44, I644-54, 1647-52, I656, I663-64, I664-67, I665-66, I668, I675-76, I676-85, I679, I681, I710-I2, I720-22, I738, I743, I770-72, I772-72. Turkey, and Ming China”. Comparative Studies in Society and History, v. 30, n. I, p. I03-I42, 1988.

40 GÜRKAN, E. S. "Salgin Hastaliklar - Olmaz Öyle Saçma Tarih! Bölüm, 24”. YouTube. Available from: «https://www.youtube.com/watch?v=LtsgTWG-rRw». 


\section{REVISTA ANGELUS NOVUS}

there were speculations that the British were complicit in spreading the disease. ${ }^{42}$ By consequence, it led to civil unrest, disobedience, and rioting. In I897, the Chapekar brothers shot down the Pune Special Plague Committee chairman and his deputy, which was seen as an act of terrorism by the colonial regime. ${ }^{43}$ All three brothers and an accomplice were hanged; another accomplice, a schoolboy, was sentenced to Io years of rigorous imprisonment. The Indian nationalist and independence activist Bal Gangadhar Tilak was charged with sedition for his writings and was sentenced to 18 months of rigorous imprisonment. ${ }^{44}$ As a result, the city of Pune ${ }^{45}$ became the epicentre of social reform, nationalism, and Indian independence movement.

\section{Another Deadly Pandemic: Cholera}

Cholera entered the world stage in the eighteenth century. Although there were several suspicions of cholera outbreaks in history (e.g., sixth century BCE cholera-like symptoms in an Indian text; an outbreak of acute diarrhea in the sixteenth century in East Indies; acute diarrhea reports from China in 1669 , etc.), there is no hard evidence for it prior to 178I. Compared to bubonic plague, the death toll of the first world cholera pandemic was very limited; though, it triggered stigmatization, violence, and racism towards Asian people, especially an anti-Indian sentiment in the West. ${ }^{66}$ As Aeschylus famously remarked in The Judgment of Hypermnestra: "Everyone is quite prepared to blame a foreigner." William Eggleston was blaming the "Mohammedan pilgrims" for the cholera outbreak,47 and the British authorities classified pilgrims as "dangerous class" by placing them under specific surveillance. ${ }^{48}$ In sum, social

42 CHANDAVARKAR, R. "Plague Panic and Epidemic Politics in India, I896-19I4”. SLACK, P.; RANGER, T. (Ed.). Epidemics and Ideas: Essays on the Historical Perception of Pestilence. Cambridge: Cambridge University Press, 1992. p. 203-240.

43 UZ ZAMAN, R. "Bengal Terrorism and the Ambiguity of the Bengali Muslims". NHIMAKI, H.; BLEMENAU, B.; HANHIM KI, J. (Ed.). An International History of Terrorism: Western and Non-Western Experiences. London: Routledge, 2008.

44 KAMRA, S. "Law and Radical Rhetoric in British India: The I897 Trial of Bal Gangadhar Tilak". Journal of South Asian Studies, v. 39, n. 3, p. 546-559, 2016.

45 Mahatma Gandhi was in tandem as one of prisoners in the Yerwada Central Jail in this city, where both his wife Kasturba Gandhi and aide Mahadev Desai died.

46 COHN, S. K. "Pandemics: Waves of Disease, Waves of Hate from the Plague of Athens to AIDS". The Historical Journal, v. 85, n. 230, p. 535-555, 2012.

47 EGgLESTON, W. G. "Oriental Pilgrimages and Cholera”. The North American Review, v. 155, n. 428, p. 126 I28, I892.

48 SAGAREE, J. "Anti-Asian Racism in the I8I7 Cholera Pandemic". JSTOR Daily. Available from: «https://daily.jstor.org/anti-asian-racism-in-the-I8I7-cholera-pandemic».

Io $\bullet$ ano XII, n. I7, 202I • ISSN 2179-5487 
scapegoating led to exclusion of minority groups, suspension of civil rights, and increase in authoritarianism in British colonies.

The second world cholera pandemic reached Russia in 1830, the United States in I832, and, after a long distance, Italy in I837. Again there were poignant conditions: on the one hand xenophobia towards minorities, among them Irish immigrants in New York and Boston, ${ }^{49}$ and on the other people who could not even organize a funeral for their loved ones. The well-known charnel house, Cimitero delle Fontanelle, testifies to dire consequences of the plague in Naples. Thousands of anonymous bodies have been deposited in that ossuary. The last plague victims at Fontanelle cemetery seems to have been dropped in the wake of this cholera pandemic. Count Giacomo Leopardi, who is considered one of the greatest Italian poets, also died during this outbreak. His remains were not buried in a common grave or charnel house, which was one of the strict hygiene regulations of the time, but in the atrium of Chiesa di San Vitale Martire. Leopardi owes this to his friend Antonio Ranieri's advocacy with the authorities. The tomb of Leopardi was later moved to Parco Virgiliano - a site that is a tribute to poet Virgil - and proclaimed as a national monument..$^{\circ}$

\section{The Conquer Through Smallpox}

The Spanish conquistador Hernán Cortés would never have been able to colonize the Aztec civilization - an empire of an estimated 16 million people at the time without the smallpox outbreak. The origin of smallpox is unknown, but in ancient times, it existed in Egypt, India and China, and came to Europe after the eleventh century's Crusades. It remained endemic in these parts of the world for hundreds of years. When Europeans began to explore other parts of the world, they were vectors of these Variola germs. At that time, the Europeans were possessing natural immunity to this germ, but it was unknown to the Aztecs. Toribio de Benavente (also known as Motolinía), one of the twelve Franciscan friars who accompanied Cortés, provided the following description:

As the Indians did not know the remedy of the disease, they died in heaps, like bedbugs. In many places it happened that everyone in a house died, and as it was impossible to bury

SCHAMA, S. "Plague Time: Simon Schama on What History Tells Us". Financial Times, London, Io Apr. 2020. Available from: «https://www.ft.com/content/279dee4a-740b-Irea-95fe-fcd274e920ca». 


\section{REVISTA ANGELUS NOVUS}

the great number of dead, they pulled down the houses over them, so that their homes became their tombs. ${ }^{\mathrm{Ir}}$

Variola was an airborne virus that rapidly transmitted from one person to another through inhalation. On top of this, there were other diseases introduced in the New World by Europeans, being measles, mumps, and salmonella. Altogether, it reduced $90 \%$ or more of the indigenous population, including Mayan and Incan civilizations.

Smallpox was likewise an attractive agent for biological warfare. In the eighteenth century, British colonists tried to contaminate Native Americans. A commander wrote: "Out of our regard for them [two Indian chiefs], we gave them two blankets and a handkerchief out of the smallpox hospital. I hope it will have the desired effect." ${ }^{2}$ Sometimes science can be a catalyst in killing large numbers of people: the American, British, Japanese, and Soviet scientists considered producing smallpox as a biological weapon during World War II. The United States stopped conducting biological weapons in 1969, whereas the Soviet Union stopped in 1992.53

\section{The Spanish Flu}

The Spanish flu in 1918 infected approximately a third of the world population at the time, and was the deadliest pandemic in human history. The first cases of the outbreak were recorded in Haskell County, Kansas, and Fort Riley. ${ }^{54}$ The influenza caused over 50 million deaths worldwide, with about 675,000 in the United States. The malnutrition and ubiquity of war standards made the situation worse. The United States was involved in World War I, but it was at the same time dealing with the deadly influenza. One of the hardest choices of president Woodrow Wilson had to make was sending troops to Europe during this outbreak.

It is even believed that the pandemic hindered the major spring offensive of general Erich Ludendorff to Paris. As a matter of fact, the disease is blamed for the failure of Germany: "It was a grievous business having to listen every morning to the

STEARN, W. E.; STEARN, A. E. "Smallpox Immunization of the Amerindian". Bulletin of the History of Medicine, v. 13, n. 5, p. 60I-613, 1943 .

53 LIGON, B. L. "Plague: A Review of Its History and Potential as a Biological Weapon". Seminars in Pediatric Infections Diseases, v. 17, n. 3, p. I6I-I70, 2006.

54 KANSAS HISTORICAL SOCIETY. "Flu Epidemic of 1918". Available from: «https://www.kshs.org/kansapedia/flu-epidemic-of-1918/I7805».

I2 • ano XII, n. I7, 2021 • ISSN 2I79-5487 
chiefs of staff's recital of the number of influenza cases, and their complaints about the weakness of their troops."ss

World War I, the Spanish flu, and probably the rise of Communism created a perception that the world was inane, grotesque, unbearable, and chaotic. Everyday life felt ridiculous. These circumstances intensified the absurdity of the moment and manifested itself into an anti-rationalist art movement (artsy version of nihilism): the Brotherhood of Dada. There was a propensity among both literary and plastic artists to mock things in a meaningless way. This was a means for them to attack the sanctimonious values of the then civilized world. A verse of the poet Richard Hülsenbeck tragicomically summarizes the spirit of the time: "Death is a thoroughly Dadaist affair."

One of the most remarkable innovations of the Spanish flu came in heating engineering. The contemporary heating systems and radiators were more than so years old, but the influenza outbreak made the engineers design radiators to heat buildings in the winter with all the windows open, for the reason that fresh air is one of the most effective ways to ward off airborne viruses. During this health crusade, the Board of Health of New York City ordered that windows should remain open to provide ventilation. ${ }^{6}$ People called unventilated air, "national poison," which is very interesting in view of the fact that this belief originated before the modern germ theory of disease. ${ }^{57}$

The simplicity of steam heat systems made them incredibly durable. They have lasted for generations. Human comfort was prevalent in the twentieth century, and we were little sensitized about the release of excess greenhouse gas emissions. As a consequence, roughly $70 \%$ of residential buildings in New York City are at present chronically overheated in winter..$^{8}$ Almost $70 \%$ of the city's carbon emission is said to come from residential buildings where fossil fuels and hot water are used for heat. Steam's grip on the existing building stock has made it much harder to achieve the environmental goals. 59

55 LUDENDORFF, E. Ludendorff's Own Story, August 1914-November 19I8; The Great War from the Siege of Liege to the Signing of the Armistice as Viewed from the Grand Headquarters of the German Army. Andesite Press, 2010.

56 HOLOHAN, D. The Lost Art of Steam Heating. New York: Dan Holohan Associates, 1992.

57 Ibidem.

58 URBAN GREEN COUNCIL. Demystifying steam. New York: Urban Green Council, 2019.

59 SISSON, P. "Your Old Radiator Is a Pandemic-Fighting Weapon: Turn-of-the-Century Faith in Ventilation to Combat Disease Pushed Engineers to Design Steam Heating Systems That Still Overheat Apartments Today”. Bloomberg. Available from: «https://www.bloomberg.com/news/articles/2020-08-05/the-curioushistory-of-steam-heat-and-pandemics». 


\section{REVISTA ANGELUS NOVUS}

If we consider the I92os as the aftermath of the pandemic, we can observe a social euphoria. After a serious pandemic, people often feel a renewed sense of purpose and possibility: the I920s, or the Roaring Twenties, brought widespread use of radio, dancehalls, jazz, Harlem Renaissance, gay and lesbian scenes, and (from I9ıо onwards) women's suffrage. ${ }^{60}$ The openly hedonistic culture of young people was possibly shocking for the older generations. ${ }^{61}$ Today, there are so many social and sexual subcultures that it is no longer seen as moral decadence in most countries. Thus, a new Roaring Twenties cannot be considered as a trend for the 2020s, since there is already tolerance for this mainstream behavior.

\section{The Coronavirus Pandemic}

SARS-CoV-2 spreads through human-to-human contact, more specifically by respiratory droplets that are produced during exhalation (e.g., breathing, speaking, singing, coughing, sneezing). There are many different measures governments can take in preventing this kind of germs, but an isolation or lockdown works quite well.

After the announcement of first lockdowns, there was social panic in some circles, shopkeepers feared their shops would be looted, empty streets seemed ominous. The normalization of life seemed far away, and there were speculations about a postapocalyptic world. That was true for an unfortunate minority, as we know from psychologists that some mental disorders are triggered from environmental stressors. ${ }^{62}$ Yet, for centuries people have survived hardships: most people will bounce back. ${ }^{63}$ The post-pandemic period will likely give expressions to joie de viure and indulgence, but not to increased joie de vivre and overindulgence. Post-pandemic Wuhan was a case in point for the rest of the world: they have organized a water park music festival in the midst of 2020, and a crowded light show during the New Year's Eve.

As far as art is concerned, we initially thought that there were two trends: I) demonstration of the sad beauty of streets without people by photographers, and 2) maintaining sexual excitement through sexting because of the low frequency of sexual intercourse, and by consequence nude selfies were considered as high art. ${ }^{64}$ More importantly, the crypto art market with the non-fungible token (NFT) technology has

6o CHRISTAKIS, N. A. Apollo's Arrow: The Profound and Enduring Impact of Coronavirus on the Way We Live. Little, Brown Spark, 2020.

6I Ibidem.

62 TAYLOR, S. The Psychology of Pandemics: Preparing for the Next Global Outbreak of Infectious Diseases. Newcastle: Cambridge Scholars Publishing, 2019.

63 Ibidem.

I4 $\bullet$ ano XII, n. I7, 202I • ISSN 2179-5487 
shaken the art world. Some artists were selling their artworks for free on the Internet, while the same artists now receive thousands of dollars for similar artworks thanks to this technology.

The economic sequelae ${ }^{6 s}$ of the coronavirus pandemic seem to be perpendicularly different. The economy during bubonic plague was a zero-sum economy: more deaths meant higher living standards for the survivors. However, the current economy is a positive-sum economy: a collaborative economy where the welfare depends on fellow citizens. In the fourteenth century Europe, there was a transition from feudalism to capitalism. Coronavirus will perhaps not overthrow our economic system, but there is a change going on. Inevitably, people accelerated this process of change. We have managed to become technology nerds in such a short time, especially the elderly people who made their way to digital platforms during the pandemic. This power allows the "new technology elite" to reshape everything: media, democracy, production, economy, finance, etc. ${ }^{66}$ A study calculated that by 2025 , the operating time of machines and working hours of humans will be equal. ${ }^{67}$ However, automation and AI are not creating additional jobs. AT\&T, the most valuable company in the United States in 1964, had 758,6II employees; as of 2019, Apple has around 137,000 employees. ${ }^{68}$

The political and economic institutions are not ready for the pending changes. We have seen that the pandemic has deepened the institutional fault lines on the grounds that there is I) erosion of expertise and autonomy in institutions, and 2) collapse in trust in institutions, ${ }^{69}$ both national (e.g., parliaments, police departments, healthcare systems) and international (e.g., WHO). Historically, the trust in institutions is higher in authoritarian countries, such as China, Singapore, and India; while the trust in the United States, Italy, and France took a hit in the last years. ${ }^{\circ 0}$

64 KAMBHAMPATY, A. P. "How Art Movements Tried to Make Sense of the World in the Wake of the I9I8 Flu Pandemic". Time, New York, 5 May 2020. Available from: «https://time.com/582756I/1918-flu-art».

65 Long-term effects of a temporary happening.

66 KAMBHAMPATY, A. P. "How Art Movements Tried to Make Sense of the World in the Wake of the I9I8 Flu Pandemic”. Time, New York, 5 May 2020. Available from: «https://time.com/5827561/1918-flu-art».

67 WORLD ECONOMIC FORUM “The Future of Jobs Report 2020". Available from: «https://www.weforum.org/reports/the-future-of-jobs-report-2020/digest».

68 SEMUELS, A. "Millions of Americans Have Lost Jobs in the Pandemic - And Robots and AI Are Replacing Them Faster Than Ever". Time, New York, 6 Aug. 2020. Available from: «https://time.com/5876604/machines-jobs-coronavirus».

69 ACEMOGLU, D. “The Post-COVID State”. Project Syndicate, 5 Jun. 2020. Available from: «https://www.project-syndicate.org/onpoint/four-possible-trajectories-after-covidi9-daron-acemoglu-2020o6?barrier=accesspaylog».

70 RAUH, J. "Is Trust in Government Really Declining? Evidence Using the Sequential Probability Ratio Test”. Acta Politica, v. 56, p. 500-529, 202I. 


\section{REVISTA ANGELUS NOVUS}

In countries where information circulates freely, citizens can hold their government accountable. The free media was one of the reasons why the 1918 influenza pandemic was called "the Spanish flu," because it was allowed to circulate news about the influenza in Spain. The media censorship in present-day China might have helped the country to avoid the term "the Chinese virus."

Another pitfall of pandemic is that it can lead to the degradation of rule of law. Democratic states must be able to argue why they are implementing certain measurements, albeit it is to control the pandemic. Measurements not only have to be useful, they also have to be necessary. Some states have circumvented the traditional legislative process to impose lockdown fines. They have to respect the usual process of law making, considering the fact that the current way of working can set a precedent. Even during a pandemic, the constitution cannot be swept aside.

\section{Conclusion $^{71}$}

Contrary to popular belief, no lessons have been learned from history because there are simply no lessons to be learned from it. Friedrich Engels once wrote in a letter to his friend Karl Marx that "everything [is] to be re-enacted twice over, once as grand tragedy and the second time as rotten farce," ${ }^{72}$ which is another way to say that history never repeats itself and definitely not in the same way. We have not seen any historical recurrence in this account as well, but the torch of knowledge must remain lit. This essay showed that pandemics have varying but considerable effects on humanity. We have retrospected to the disappointment of Athenians towards their gods in the fifth century BCE, the ending of Classical Era in the fifth century, the transition to another market system in the fifteenth century, the conquer of Latin America in the sixteenth century, a series of misfortunes in China, the Ottoman Empire, France and Spain in the seventeenth century, the rise of Hindu independence movement in the nineteenth

7I Perhaps this subject was not suitable to be explained in quantitative terms as people developed 'corona fatigue,' and numbers became meaningless. Take the example of this numerical delusion: I million seconds equals II and $1 / 2$ days, but I billion seconds equals $3 \mathrm{I}$ and $3 / 4$ years. Exponential growth is usually not intuitive and difficult to understand. Even during a pandemic the morbidity and mortality data are being perceived as trite for some people. However, if we compare the general trends of the coronavirus pandemic with the past pandemics, we cannot say that we did not make the grade. Even at a time when population movements were a fraction of what they are today, far more people died during disease outbreaks. In the pre-corona era, considering human overpopulation, virologists were gloomy about the mortality rates of a potential pandemic. Unlike their predictions, the opposite was true. Humanity can look back on what has been achieved and can be proud of it. The production of various effective coronavirus vaccines in less than a year is a case in point.

72 Engels to Marx, Manchester, 3 Dec. 1851. Marx Ef Engels Collected Works, Vol. 38: Marx-Engels: 1844-5I, Letters. London: Lawrence Wishart, 1982. p. 505.

I6 • ano XII, n. I7, 202I • ISSN 2179-5487 
century, the breakthrough in infectiology and new art movements in the twentieth century. Each major outbreak left a different footprint in our world and transformed our societies dramatically in some ways. The twenty-first century will undoubtedly bring many novelties, but let us hope that it does not end in - stated in Hobsbawmian nomenclature - "The Age of Diseases." 